\title{
Serum immunoreactive erythropoietin of children in health and disease
}

\author{
K.-U.Eckardt ${ }^{1}$, W. Hartmann ${ }^{2}$, U. Vetter ${ }^{2}$, F.Pohlandt ${ }^{2}$, R. Burghardt ${ }^{3}$, and A.Kurtz ${ }^{1}$ \\ ${ }^{1}$ Physiologisches Institut der Universität Zürich, Winterthurerstrasse 190, CH-8057 Zürich, Switzerland \\ ${ }^{2}$ Kinderklinik der Universität Ulm, Prittwitzstrasse 49, D-7900 Ulm, Federal Republic of Germany \\ ${ }^{3}$ Kinderklinik der Universität Marburg, Deutschhausstrasse 12, D-3550 Marburg, Federal Republic of Germany
}

\begin{abstract}
Serum immunoreactive erythropoietin (siEPO) was determined in cord serum from neonates $(n=97$, gestational age $36-43$ weeks), in healthy children from birth to adolescence $(n=260)$ and in children with haematological $(n=30)$, renal $(n=10)$ and congenital heart diseases $(n=70)$. In healthy children siEPO levels decreased after birth (geometric mean cord $\mathrm{siEPO} 35.6 \mathrm{mU} / \mathrm{ml}$ with $95 \%$ range of $17-56 \mathrm{mU} / \mathrm{ml}$ in eutrophic, nondistressed fetuses) and reached lowest values during the first 2 months (geometric mean siEPO $11.5 \mathrm{mU} /$ $\mathrm{ml}$ ). Thereafter siEPO levels increased slightly and were constant between 2 months and adolescence. The geometric mean siEPO for healthy children after birth was $18.8 \mathrm{mU} / \mathrm{ml}$ with $95 \%$ range of $7-47 \mathrm{mU} / \mathrm{ml}$. These estimates were not significantly different from normal adult values. In newborns with fetal distress $(n=15)$ cord siEPO was significantly elevated (geometric mean $63.0 \mathrm{mU} / \mathrm{ml} ; P<0.001$ ). In children with haematological disease, siEPO and $\mathrm{Hb}$ concentration were inversely correlated $(\log$ siEPO $(\mathrm{mU} / \mathrm{ml})=4.1-0.20 \times \mathrm{Hb}$ $(\mathrm{g} / \mathrm{dl}) ; r=-0.62 ; P<0.0005)$. This relationship was significantly different in children with chronic renal failure (log $\operatorname{siEPO}(\mathrm{mU} / \mathrm{ml})=0.67+0.035 \times \mathrm{Hb}(\mathrm{g} / \mathrm{dl}) ; r=0.50 ; P=0.1)$. In children with heart disease the geometric mean siEPO was $19.2 \mathrm{mU} / \mathrm{ml}$ with $95 \%$ range $8-65 \mathrm{mU} / \mathrm{ml}$ for cyanotic $\left(\mathrm{SaO}_{2}\right.$ $<94 \%$ ) and $17.7 \mathrm{mU} / \mathrm{ml}$ with $95 \%$ range of $12-36 \mathrm{mU} / \mathrm{ml}$ for acyanotic patients. In this group siEPO values were inversely correlated to the arterial oxygen content $(\log \operatorname{siEPO}(\mathrm{mU} / \mathrm{ml})$ $=1.61-2.04 \times$ oxygen content $(1 / 1) ; r=-0.28 ; P<0.02)$.
\end{abstract}

Key words: Newborn - Erythropoiesis - Anaemia - Congenital heart disease - Renal failure - Arterial oxygen content

\section{Introduction}

Erythropoietin (EPO) is considered the primary regulator of red cell formation [20]. The development of sensitive radioimmunoassays for the estimation of EPO allows the routine measurement of the hormone in biological fluids. In order to determine whether disorders of erythropoiesis are related to inappropriate EPO production, normal values and their alter-

Offprint requests to: $\mathrm{K}$.-U. Eckardt

Abbreviations: $\mathrm{EPO}=$ erythropoietin; $\mathrm{siEPO}=$ serum immunoreactive erythropoietin ations in different diseases must be established. In adults normal serum values and the physiological relationship of serum EPO levels to $\mathrm{Hb}$ concentration are well known $[2,5,7,8,10$, $16-18,24]$. Less information is available, however, on EPO levels in childhood. Only recently have values from healthy children between birth and 16 years been reported [12]. In previous studies in children with conditions such as prematurity, cardiopulmonary, haematological and renal disorders $[1$, $3,4,11,15,19,22]$, estimates were generally related to adult levels because values in normal children were not available. It was the intention of this study to determine the age and sex distribution of serum EPO concentrations in healthy children between birth and adolescence. Furthermore, we studied the relationship of serum EPO levels to arterial oxygen content in children with haematological, renal and congenital heart diseases and compared these parameters with those of healthy infants.

\section{Subjects and methods}

The study was carried out according to the principles of the Declaration of Helsinki.

\section{Newborns}

Cord serum samples were obtained immediately after birth from 97 consecutively delivered neonates (gestational age 3643 weeks). Eight of these newborns suffered from intrauterine hypothrophy. Fifteen newborns had signs of fetal distress, when defined as $1 \mathrm{~min}$ Apgar score below 7 or umbilical artery $\mathrm{pH}$ below 7.2.

\section{Healthy children}

Serum samples of 260 healthy children (age 1 day-15 years) and 14 adolescents (age 16-20 years) were available for analysis. All children and adolescents participated in a growth study with the informed consent of the parents and the ethical committee of the University of Ulm, Federal Republic of Germany.

\section{Adult controls}

For comparison, serum immunoreactive erythropoietin (siEPO) levels were also determined in 84 adults (age range 21-87 years) 
with their informed consent. These were either members of laboratory staff or medical in-patients for elective eye surgery. None suffered from a haematological, cardiopulmonary or renal disease, as confirmed by case history and routine laboratory tests.

\section{Children with haematological disorders}

$\mathrm{SiEPO}$ was measured in 30 children (age 2-16 years) with anaemias of various aetiologies. In 15 patients anaemia was due to an aregenerative bone marrow, including severe aplastic anaemia, pure red cell aplasia and Blackfan Diamond disease. The other 15 children suffered from $\beta$-thalassaemia and were periodically transfused every 3 to 4 weeks. All children had normal renal function. None had received transfusions for at least 2 weeks prior to blood sampling for determination of serum EPO. Arterial oxygen content was calculated from $\mathrm{Hb}$ concentrations (see below) assuming $97 \% \mathrm{SaO}_{2}$.

\section{Children with renal failure}

Ten patients with renal failure were investigated (age 2-16 years). One had acute renal failure due to haemolytic uraemic syndrome, and nine suffered from chronic renal failure of various aetiologies (two cases each with nephronophthisis, obstructive uropathy and glomerulonephritis, and one case each with congenital renal hypoplasia, Alport syndrome and interstitial nephritis). Glomerular filtration rate ranged from 7 to $55 \mathrm{ml} / \mathrm{min}$ with a mean of $26 \mathrm{ml} / \mathrm{min}$. None of these children received recombinant EPO or had undergone renal transplantation.

\section{Children with congenital heart disease}

Seventy patients with various forms of congenital heart disease were studied (age 3 days-16 years). These included 32 patients with single malformations (atrial or ventricular septal defect, persistent ductus arteriosus, pulmonary or aortic valve stenosis, hypoplastic left ventricle and transposition or great arteries) and 38 patients with complex vitia. All patients had normal serum creatinine values. Cyanosis was considered present if $\mathrm{SaO}_{2}$ was less than $94 \%$ and absent if $\geq 94 \%$. Arterial oxygen content was calculated as follows: $\mathrm{SaO}_{2} \times \mathrm{Hb}(\mathrm{g} /$ dL) $\times 1.34$.

\section{Radioimmunoassay for EPO}

$\mathrm{SiEPO}$ was determined by radioimmunoassay exactly as described [6]. In brief, $100 \mu 1$ samples plus $20 \mu \mathrm{l}$ of $30 \%$ bovine serum albumin were incubated with $100 \mu \mathrm{l}$ rabbit antiserum raised against recombinant human EPO for $24 \mathrm{~h} .100 \mu \mathrm{l}$ of tracer $\left(8 \times 10^{-11} \mathrm{~mol} / \mathrm{l}{ }^{125} \mathrm{I} \mathrm{EPO}\right.$; Amersham International, Amersham, UK) were then added and after an additional incubation period of $24 \mathrm{~h}$ free and bound ligand were separated using a second antibody technique. As a standard we used the 2nd International Reference Preparation of human urinary EPO (WHO).

\section{Data evaluation and statistics}

Since serum EPO levels were approximately log-normally distributed (see results), EPO levels were log-transformed for plotting and calculations and geometric means were calculated for groups of observations. Unpaired Student $t$-test was used for comparison of groups and analysis of variance to determine significance levels of linear regressions. A $P$-value $<0.05$ was considered to be significant.

\section{Results}

\section{Healthy children}

SiEPO concentrations of 260 healthy children (age 1 day-15 years) ranged from 5 to $95 \mathrm{mU} / \mathrm{ml}$. The geometric mean was $18.8 \mathrm{mU} / \mathrm{ml}$ and the $95 \%$ range $7-47 \mathrm{mU} / \mathrm{ml}$. Only two children had siEPO levels higher than $54 \mathrm{mU} / \mathrm{ml}$ and were therefore analysed separately. The frequency distribution of siEPO for the remaining 258 children (131 boys and 127 girls) is shown in Fig. 1. After log-transformation, siEPO values in boys and girls were approximately normally distributed. There was no sex difference for the whole group (geometric mean $18.6 \mathrm{mU} / \mathrm{ml}$ for boys and $18.8 \mathrm{mU} / \mathrm{ml}$ for girls) or at any age.

Figure 2 shows the distribution of siEPO values in relation to age for (i) the above 258 healthy children, (ii) 75 nondistressed, eutrophic newborns (cord siEPO), (iii) healthy adolescents $(n=14$; age range $16-20$ years; geometric mean 21.4 $\mathrm{mU} / \mathrm{ml} ; 95 \%$ range from 13 to $36 \mathrm{mU} / \mathrm{ml}$ ) and (iv) normal adults ( $n=84$; geometric mean $17.9 \mathrm{mU} / \mathrm{ml} ; 95 \%$ range from $11-31$
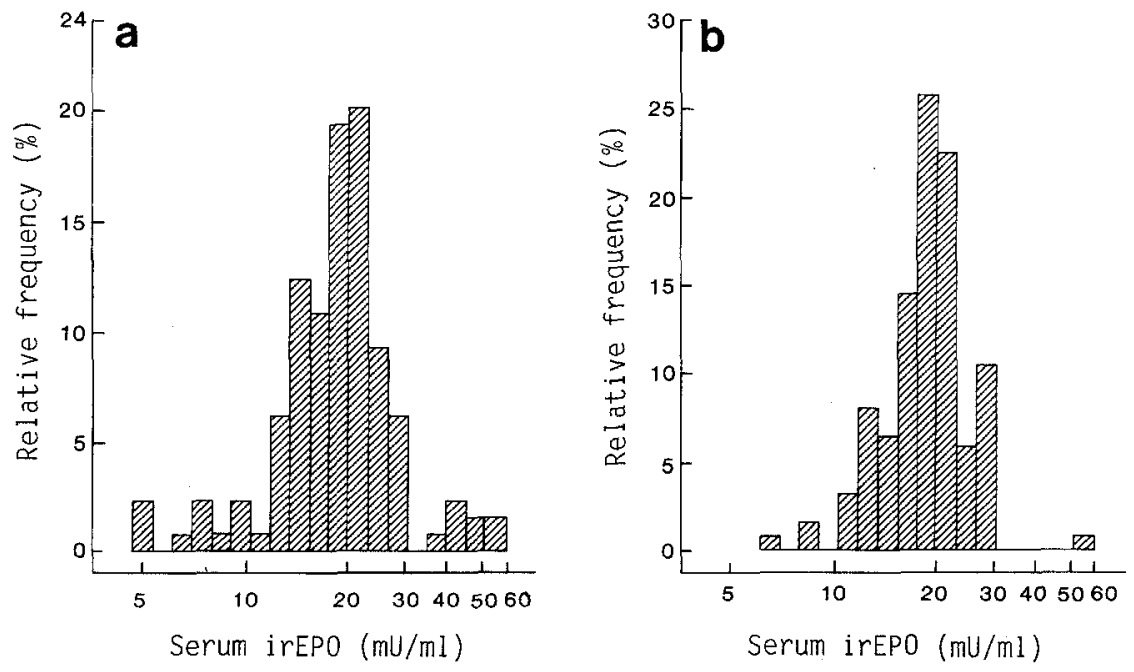

Fig. 1a,b. Frequency distribution of log-transformed siEPO levels in healthy a boys $(n=131)$ and $\mathbf{b}$ girls $(n=127)$ 


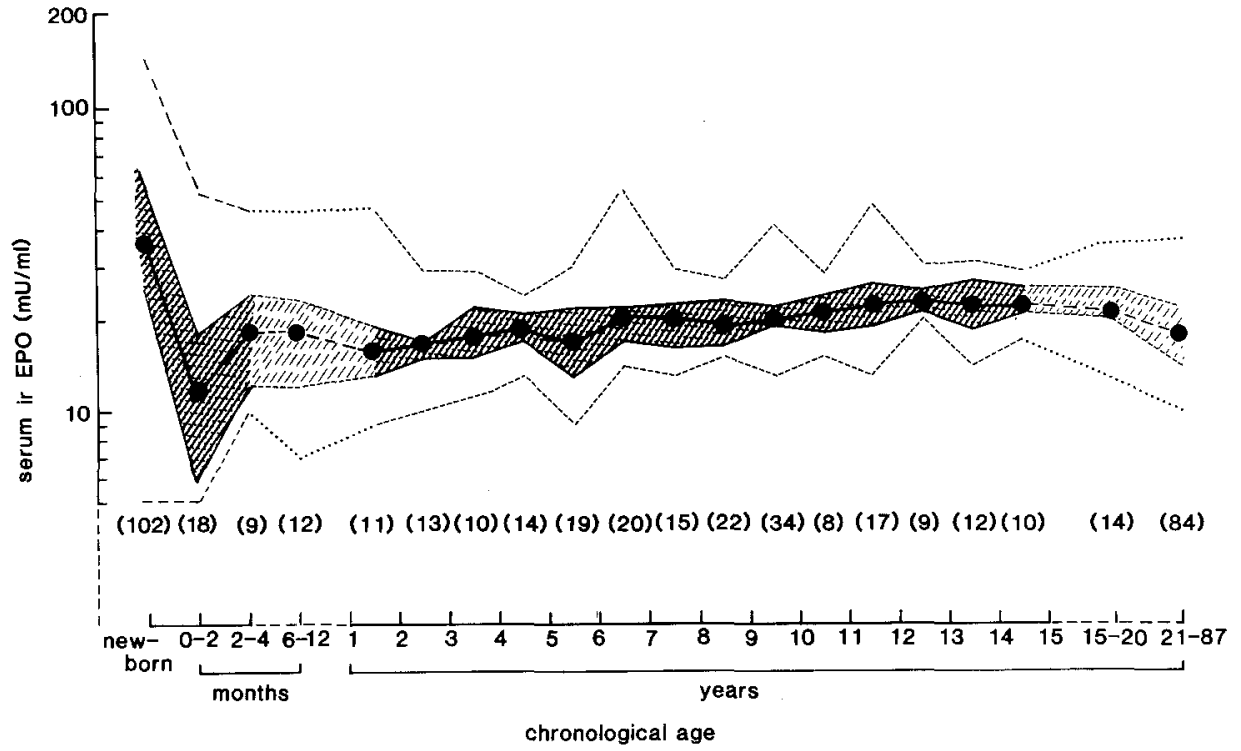

Fig. 2. Estimates of siEPO in healthy children in relation to age. For comparison values of healthy adolescents and healthy adults are included. Values are geometric mean, interquartile range and total range
Table 1. Serum EPO values in children between 1 and 40 days after birth

\begin{tabular}{|c|c|c|c|}
\hline Age (days) & Sex & siEPO $(\mathrm{mU} / \mathrm{ml})$ & Haematocrit (\%) \\
\hline 1 & M & 12 & 0.67 \\
\hline 1 & M & 13 & 0.70 \\
\hline 1 & M & 7 & 0.65 \\
\hline 1 & $\mathrm{~F}$ & 12 & 0.72 \\
\hline 1 & M & 53 & 0.71 \\
\hline 1 & M & 10 & 0.65 \\
\hline 2 & $\mathrm{~F}$ & 12 & 0.66 \\
\hline 2 & M & 7 & 0.62 \\
\hline 2 & M & 12 & 0.62 \\
\hline 10 & M & 6 & 0.49 \\
\hline 15 & M & 5 & 0.43 \\
\hline 20 & $\mathrm{~F}$ & 6 & 0.29 \\
\hline 20 & $\mathrm{~F}$ & 53 & 0.44 \\
\hline 20 & M & 17 & 0.48 \\
\hline 30 & M & 5 & 0.40 \\
\hline 30 & M & 18 & 0.39 \\
\hline 30 & M & 23 & 0.46 \\
\hline 40 & M & 5 & 0.45 \\
\hline
\end{tabular}

$\mathrm{mU} / \mathrm{ml})$. Through childhood, from age 2 months to 15 years, siEPO was essentially constant and the same as found in adults. In younger infants estimates of siEPO were different. In cord blood of healthy newborns we found a geometric mean of $35.6 \mathrm{mU} / \mathrm{ml}(95 \%$ range $17-56 \mathrm{mU} / \mathrm{ml})$, which was significantly higher than in children after birth $(P<0.001)$. In children aged 1 day to 2 months, geometric mean siEPO was $11.5 \mathrm{mU} /$ $\mathrm{ml}(95 \%$ range $5-53 \mathrm{mU} / \mathrm{ml} ; n=18)$ and significantly lower than in older children $(P<0.05)$. Individual values for children in this group are given in Table 1.

In two girls (10 and 11 years old, respectively), who were primarily included in the group of healthy children, siEPO levels were higher than in the other children $(79$ and $95 \mathrm{mU} /$ $\mathrm{ml}$, respectively). No obvious reason for the increased levels was apparent from clinical and laboratory data.

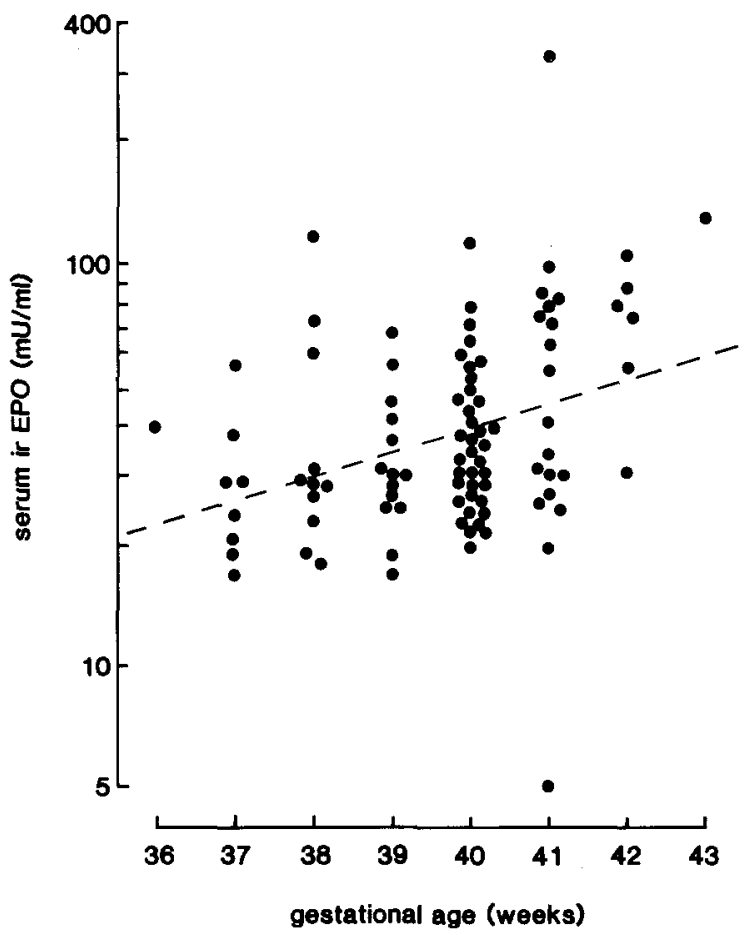

Fig. 3. Relationship of cord siEPO levels to gestational age in 97 newborns. Values fit the linear regression curve: $\log$ siEPO (mU/ $\mathrm{ml})=-0.8+0.06 \times$ gest. age (weeks) $r=0.33, P<0.002$

Hypotrophic newborns and newborns with signs of fetal distress

In hypotrophic newborns median gestational age was 37 weeks (range 36-38weeks) and median birth weight was $2150 \mathrm{~g}$ (range $1720-2350 \mathrm{~g}$ ). Geometric mean cord siEPO in these children was $29.9 \mathrm{mU} / \mathrm{ml}(95 \%$ range $17-56 \mathrm{mU} / \mathrm{ml})$ and not significantly different from eutrophic neonates with normal umbilical artery $\mathrm{pH}$ and Apgar score $(P>0.20)$.

In newborns with signs of fetal distress, defined as either 1 min Apgar score below 7 or umbilical artery pH below 7.2, median $1 \mathrm{~min}$ Apgar score was 7 (range 3-9) and median umbilical artery $\mathrm{pH} 7.18$ (range 7.13-7.27). Geometric mean 


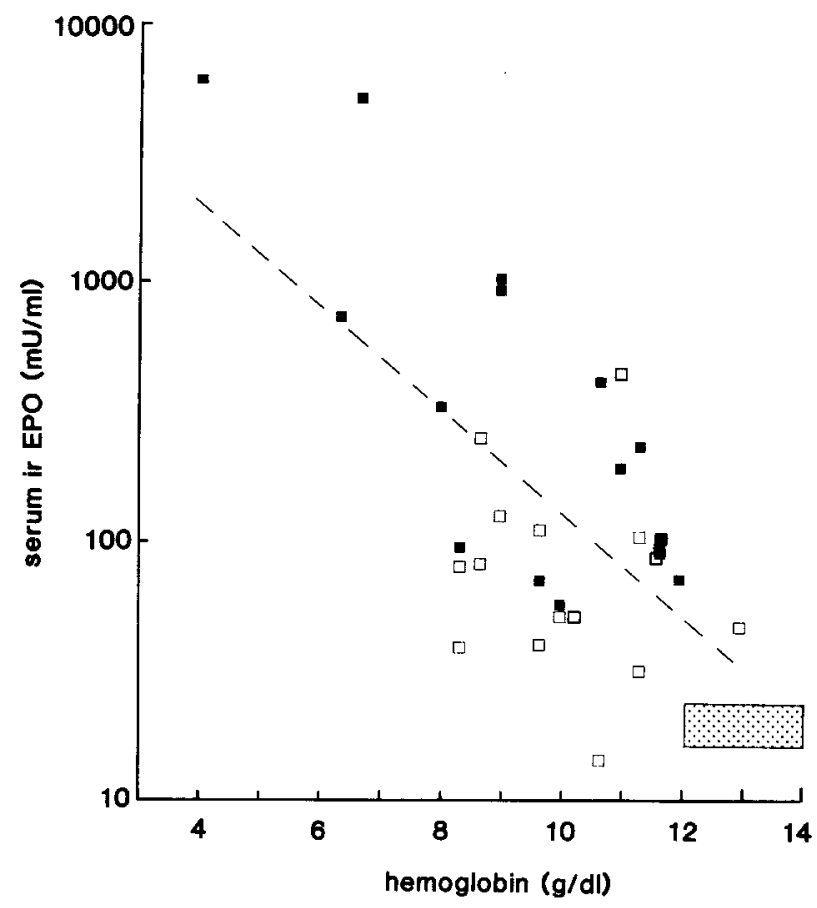

Fig. 4. Relationship of siEPO levels to $\mathrm{Hb}$ concentrations in children with bone marrow insufficiency (filled symbols) and thalassaemia (open symbols). Values fit the linear regression curve: log siEPO $(\mathrm{mU} / \mathrm{ml})=4.1-0.20 \times \mathrm{Hb}(\mathrm{g} / \mathrm{dl}) ; r=-0.62 ; P<0.0005$. Horizontal bar shows mean siEPO and interquartile range of healthy children, age $0-15$ years

cord siEPO in this group was $63.0 \mathrm{mU} / \mathrm{ml}$ (95\% range $17-331$ $\mathrm{mU} / \mathrm{ml} ; P<0.001$ vs eutrophic, nondistressed newborns). Furthermore, when values from all newborns were analysed together, a slight but statistically significant inverse correlation was found between umbilical artery $\mathrm{pH}$ and cord siEPO $(\log \operatorname{siEPO}(\mathrm{mU} / \mathrm{ml})=7.9-0.87 \times \mathrm{pH} ; r=-0.21, P<0.05)$.

In addition, in the whole group of neanates cord siEPO increased with gestational age $(\log$ siEPO $(\mathrm{mU} / \mathrm{ml})=$ $-0.8+0.06 \times$ gest. age (weeks); $r=0.33, P<0.002$ ) (Fig. 3)

\section{Anaemic children}

A relationship of siEPO to $\mathrm{Hb}$ concentrations was discovered in blood samples obtained from anaemic children with bone marrow aplasia and thalassaemia (Fig. 4). The children of this group were aged between 2 and 16 years (mean 8.2 years). SiEPO ranged between 14 and $6000 \mathrm{mU} / \mathrm{ml}$, and $\mathrm{Hb}$ between 4 and $13 \mathrm{~g} / \mathrm{dl}$. SiEPO and $\mathrm{Hb}$ concentration were inversely correlated and showed a negative linear regression when plotted on a semilogarithmic scale $(\log$ siEPO $(\mathrm{mU} / \mathrm{ml})=$ $4.1-0.20 \times \mathrm{Hb}(\mathrm{g} / \mathrm{dl}) ; r=-0.62 ; P<0.0005)$ (Fig. 3). This relationship of siEPO to $\mathrm{Hb}$ was significantly different in a group of anaemic children suffering from renal disease (log $\operatorname{siEPO}(\mathrm{mU} / \mathrm{ml})=0.67+0.035 \times \mathrm{Hb}(\mathrm{g} / \mathrm{dl}) ; r=0.50 ; P=0.1)$ (Fig. 5). This group consisted of 10 uraemic children aged between 2 and 16 years. SiEPO values remained low even during severe anaemia.

The relationship of siEPO to $\mathrm{Hb}$ was also altered in healthy children during the 1 st trimenon (Fig. 5). It appears that the values in healthy children during the 1 st trimenon are at the lower limit of those obtained in children with haematological diseases.

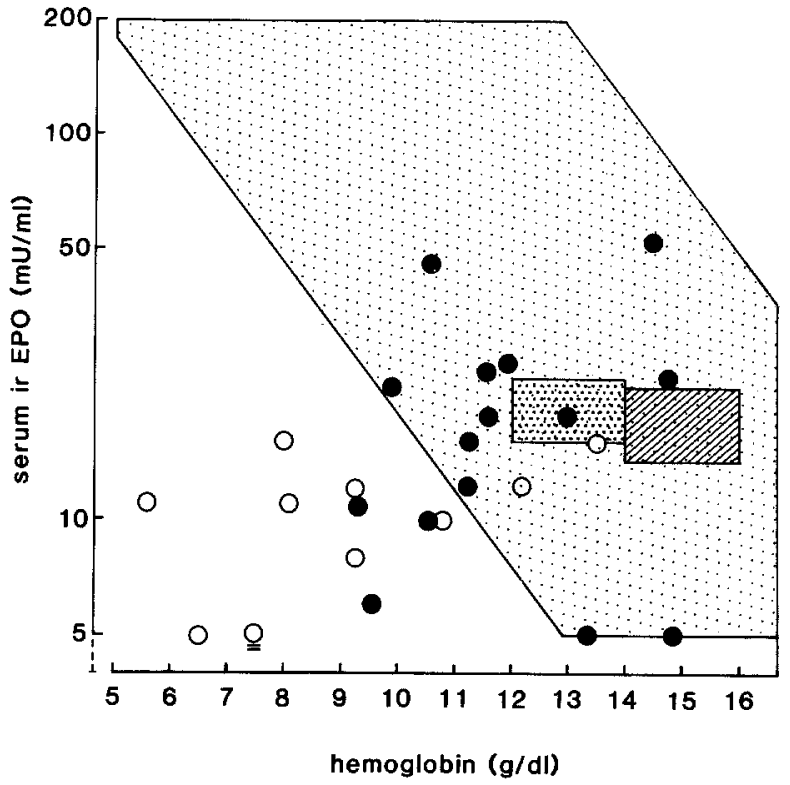

Fig. 5. Relationship of siEPO levels to Hb concentrations in ten children with renal disease (open circles) and in healthy children during age 0.5-3 months (closed circles). The dotted diagonal bar indicates the $95 \%$ confidence interval for values found in anaemic children, the horizontal bars show mean siEPO and interquartile range of healthy children, age 0-15 years (dotted) and healthy adults (hatched) (@ indicates an EPO value below $5 \mathrm{mU} / \mathrm{ml}$ )

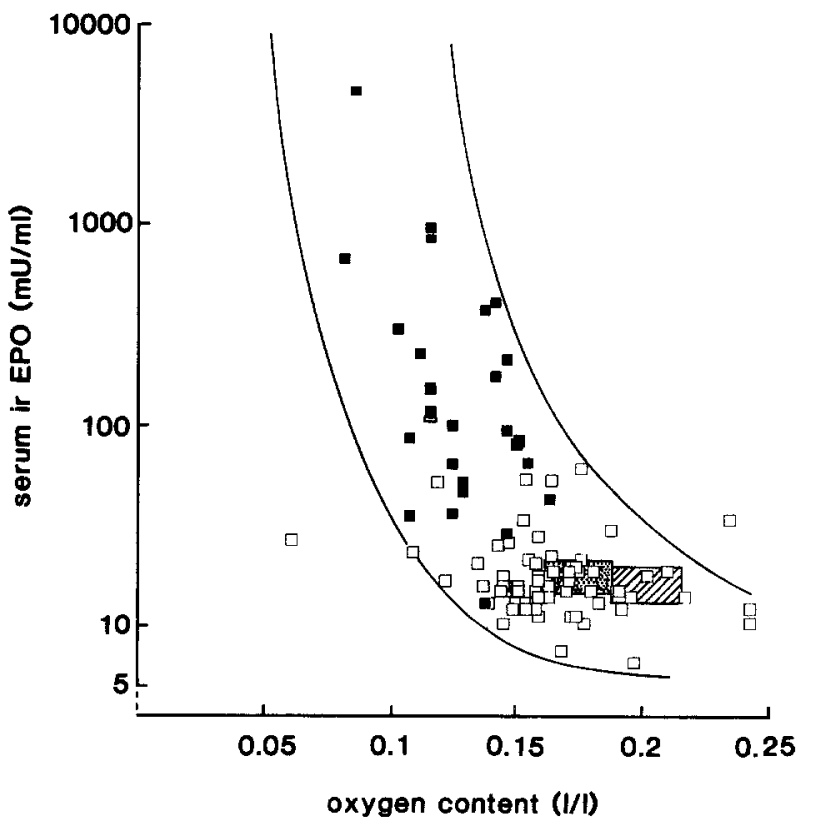

Fig. 6. Relationship of siEPO levels to arterial blood oxygen content in children with congenital heart disease (open symbols) and anaemias (closed symbols). Bars show geometric mean siEPO and interquartile range for healthy children (dotted) and adults (hatched)

\section{Children with heart disease}

We determined siEPO in 70 children with congenital heart disease, aged between 3 days and 16 years (mean 3.5 years). Fifty of them were cyanotic $\left(\mathrm{SaO}_{2}<94 \%\right)$. The geometric mean of siEPO was $19.2 \mathrm{mU} / \mathrm{ml}$ and the $95 \%$ range from 8 to $65 \mathrm{mU} / \mathrm{ml}$ for the cyanotic children. For the acyanotic chil- 
dren, the geometric mean was $17.7 \mathrm{mU} / \mathrm{ml}$ and the $95 \%$ range from 12 to $36 \mathrm{mU} / \mathrm{ml}$. The difference between cyanotic and acyanotic children was not significant. SiEPO was neither correlated with $\mathrm{Hb}$ nor with $\mathrm{SaO}_{2}$. An inverse correlation, however, was observed between siEPO and arterial oxygen content $(\log$ siEPO $(\mathrm{mU} / \mathrm{ml})=1.61-2.04 \times$ oxygen content $(1 / 1)$; $r=-0.28 ; P<0.02$ ).

It is evident from Fig. 6 that the data obtained from children with heart disease and those obtained from healthy children and children with haematological disease fit a consistent relationship of siEPO to arterial oxygen content.

\section{Discussion}

Our observation that siEPO concentrations in healthy children between 2 months of age and adolescence were not significantly different from those of healthy adults confirms previous results by Hellebostad et al. [12]. We also found no sex differences nor significant changes of siEPO during puberty (Figs. 1,2). The latter finding could indicate that the expansion or red cell mass during accelerated body growth is not primarily triggered by EPO. It supports the concept that the adaptation of red cell mass to body mass during growth is controlled by other factors such as insulin-like growth factor I [14].

$\mathrm{SiEPO}$ values in cord blood were significantly higher than serum levels during childhood and showed considerable variation (Fig. 2). The magnitude of cord serum values in our study is comparable to that reported by Thomas et al. [21]. These results extend previous investigations, that demonstrated erythropoietic activity in cord blood and 1st day urine, but not during the following weeks by employing less sensitive bioassays for EPO [9]. In addition to Thomas and coworkers, who demonstrated an increase in EPO levels from 19 weeks gestation until term [21], we found a significant increase also during late gestation (Fig. 3). The importance of EPO for the regulation of fetal erythropoiesis is further supported by previous studies, demonstrating increased EPO levels in the presence of placental insufficiency and fetal hypoxia [9, 21, 23]. Also in the present investigation EPO levels in children with signs of fetal distress were elevated and cord blood EPO was inversely correlated with umbilical artery $\mathrm{pH}$, indicating that fetal EPO production can respond to hypoxia.

During the 1st trimenon, when an anaemia develops, rather low siEPO values were found. The same observation was made by Hellebostad et al. [12] and may indicate that the physiological feedback loop between oxygen delivery and EPO production- well established for adults [8] - is less sensitive during the 1st trimenon. The idea is supported by our observation that the relationship of siEPO to $\mathrm{Hb}$ during the first 3 months was in the lower range of that obtained from older children with haematological diseases (Fig. 5). This also complies with the observation made by Brown et al. [3, 4] that in premature infants there is a decreased response of EPO production to available oxygen.

The inverse relationship of siEPO to $\mathrm{Hb}$, which we found in children with haematological disorders, agrees with the results obtained by McGonigle et al. [15] and was almost identical with that of adult patients $[8,17]$. This finding suggests that the feedback loop of EPO production as known from adults is already established during the first years of life. Due to the relatively small number of haematological patients in our study it was not possible to clearly distinguish whether the re- lationship of siEPO to $\mathrm{Hb}$ is different during ineffective and aregenerative erythropoiesis as suggested by two other studies $[15,19]$. As in adults the relationship of siEPO to $\mathrm{Hb}$ was significantly altered in children with renal failure and their anaemia was accompanied by inappropriate low levels of siEPO (Fig. 4). Inappropriate low EPO levels in uraemic children have also been observed in another study [1]. Both studies thus indicate indirectly that the kidneys are the physiological production site of EPO already during childhood.

The observation that siEPO levels in children with heart disease are not significantly different from those in healthy children are in accordance with previous reports [11,22]. On first glance it may be surprising that there is no difference in siEPO between cyanotic and acyanotic children and that, in contrast to anaemic children, there is no correlation of siEPO to $\mathrm{Hb}$ concentrations. However, EPO production is in general inversely related to renal oxygen supply [13]. In states of unphysiological oxygen saturation therefore siEPO should be inversely related to the arterial oxygen content rather than to the $\mathrm{Hb}$ concentration. In fact, such a relationship was seen in this and two other studies $[11,22]$. Moreover, we found that a consistent relationship of siEPO to arterial oxygen content resulted when the data from healthy children and children with haematological and heart diseases were combined (Fig. 6). Thus the lack of abnormal siEPO values during heart disease appears to result from a very fine tuning of the feedback loop of EPO production.

Acknowledgements. The authors wish to thank Dr. H. Eckardt for supplying them with blood samples. The generous gift of rabbit antiserum against human EPO by Dr.P. Hirth, Boehringer Mannheim, Federal Republic of Germany, is gratefully acknowledged. The artwork was done by W. Gehret. This study was in part financially supported by a grant from the Swiss National Science Foundation (grant 3.800-0.86). K.-U.E. is a recipient of a fellowship from the Deutsche Forschungsgemeinschaft.

\section{References}

1. Aikhionbare HA, Winterborn MW, Gyde OH (1987) Erythropoietin in children with chronic renal failure on dialytic and non-dialytic therapy. Int $J$ Pediatr Nephrol 8:9-14

2. Birgegard G, Miller O, Caro J, Erslev A (1982) Serum erythropoietin levels by radioimmunoassay in polycythemia. Scand J Haematol 29:161-167

3. Brown MS, Phibbs RH, Garcia JF, Dallman PR (1983) Postnatal changes in erythropoietin levels in untransfused premature infants. J Pediatr 103:612-617

4. Brown MS, Garcia JF, Phibbs RH, Dallman PR (1984) Decreased response of plasma immunoreacitve erythropoietin to "available oxygen" in anemia of prematurity. J Pediatr 105:793-798

5. Cotes PM (1982) Immunoreacitve erythropoietin in serum. I. Evidence for the validity of the assay method and the physiological relevance of estimates. Br J Haematol 50:427-438

6. Eckardt KU, Kurtz A, Hirth P, Scigalla P, Wieczorek L, Bauer C (1988) Evaluation of the stability of human erythropoietin in samples for radioimmunoassay. Klin Wochenschr 66:241-245

7. Egrie JC, Cotes PM, Lane J, Gaines Das RE, Tam RC (1987) Development of radioimmunoassays for human erythropoietin using recombinant erythropoietin as tracer and immunogen. J Immunol Methods 99:235-241

8. Erslev AJ, Wilson J, Caro J (1987) Erythropoietin titers in anemic, nonuremic patients. J Lab Clin Med 109:429-433

9. Finne PH, Halvorsen S (1972) Review article: regulation of erythropoiesis in the fetus and newborn. Arch Dis Child 47:683-687

10. Garcia JF, Ebbe SN, Hollander L, Cutting HO, Miller ME, Cronkite EP (1982) Radioimmunoassay of erythropoietin: circulating 
levels in normal and polycythemic human beings. J Lab Clin Med $99: 624-635$

11. Haga P, Cotes PM, Till JA, Minty BD, Shinbourne EA (1987) Serum immunoreacitve erythropoietin in children with cyanotic and acyanotic congenital heart disease. Blood 70:822-826

12. Hellebostad M, Haga $P$, Cotes $M$ (1988) Serum immunoreactive erythropoietin in healthy normal children. Br J Haematol 70:247250

13. Kurtz A, Eckardt KU, Tannahill L, Bauer C (1988) Regulation of eryhtropoictin production. Contrib Nephrol 66:1-15

14. Kurtz A, Zapf J, Eckardt KU, Clemons G, Froesch ER, Bauer C (1988) Insulin-like growth factor I stimulates erythropoiesis in hypophysectomized rats. Proc Natl Acad Sci USA 85:7825-7829

15. McGonigle RJS, Ohene-Frempong K, Lewy JE, Fisher JW (1985) Erythropoietin response to anemia in children with sickle cell disease and Fanconi's hypoproliferative anemia. Acta Haematol 74: 6-9

16. Mizoguchi H, Ohta K, Suzuki K, Murakami T, Ueda A, Sasaki R, Chiba H (1987) Basic conditions for radioimmunoassay of erythropoietin, and plasma levels of erythropoietin in normal subjects and anemic patients. Acta Haematol Jpn 50:15-24

17. Rege AB, Brookins J, Fisher JW (1982) A radioimmunoassay for erythropoietin: serum levels in normal human subjects and patients with hemopoietic disorders. J Lab Clin Med 100:829-843
18. Sherwood JB, Goldwasser E (1979) A radioimmunoassay for erythropoietin. Blood 54:885-893

19. Sherwood JB, Goldwasser E, Chilcote R, Carmichael LD, Nagel RL (1986) Sickle cell anemia patients have low erythropoietin levels for their degree of anemia. Blood 67:46-49

20. Spivak J (1986) The mechanism of action of erythropoietin. Int $\mathbf{J}$ Cell Cloning 4:139-166

21. Thomas RM, Canning CE, Cotes PM, Linch DC, Rodeck CH, Rossiter CE, Huehns ER (1983) Erythropoietin and cord blood haemoglobin in the regulation of human fetal erythropoiesis. Br J Obstet Gynaecol 90:795-800

22. Tyndall MR, Teitel DF, Lutin WA, Clemons GK, Dallman PR (1987) Serum erythropoietin levels in patients with congenital heart disease. J Pediatr 110:538-544

23. Voutilainen PEJ, Widness JA, Clemons GK, Schwartz R, Teramo KA (1989) Amniotic fluid erythropoietin predicts fetal distress in Rh-immunized pregnancies. Am J Obstet Gynaecol 160:429-434

24. Zaroulis CG, Hoffman BJ, Kourides IA (1981) Serum concentrations of erythropoietin measured by radioimmunoassay in hematologic disorders and chronic renal failure. Am J Hematol $11: 85-92$

Received June 8, 1989 / Accepted October 7, 1989 